\title{
The Influence of Marketing Effectiveness on Building Long-Term Relationships in a Sport Environment
}

\section{F J Herbst and A N Schreuder}

Department of Marketing and Communication Management, University of Pretoria

\section{ABSTRACT}

The providers of professional sport are influenced by the ever-changing nature of sport as a form of entertainment and its subsequent effect on relationship building in the new millennium. The continuous aim of building relationships of high quality in a lucrative business field can only be achieved by means of effective marketing. In order to ensure marketing effectiveness, the quality of the relationship with spectators is a crucial success factor, influenced by the length of the relationship, value for money and the propensity to leave. An empirical study was undertaken in a sporting environment which investigated the quality of the clients' (season ticket holders') current relationship with the service provider (sporting union). An exposition is also given of the methods and procedures used in the study.

JEL M 31

"The heart and soul of relationship marketing is marketing to the customers after they have become customers" (Berry, 1994).

\section{INTRODUCTION}

Research in relationship marketing to date concentrated on business-to-business (BTB) marketing research and little attention was given to business-to-consumer (BTC) marketing research. Relationship marketing has yet to progress beyond topics for articles and speeches with little real action (Pruden, 1995). This view is supported by Perrien (1995) and Paley (1996) who believe that the implementation of relationship marketing within organisations, including service organisations, has 
yet to be tackled.

There is a need for a model that conceptually incorporates the relationship factors that are unique in BTC marketing. An attempt was made by Morgan and Hunt (1994), with their Commitment-Trust Theory of Relationship Marketing, which was based on research conducted in the automobile tyre retailer industry. The KMV model focuses on the relationship commitment and trust of only one party in the relational exchange.

The aim of the current study is to investigate relationship marketing in general and not to direct the study at a specific industry. The empirical research was conducted on the relationship marketing of a major sport union in South Africa.

There is a lack of consensus on the correct terminology with regards to sport (singular) or sports (plural) marketing. In this study the term "sport marketing" is preferred based on Mullin, Hardy and Sutton (1993) who argue that "sports marketing" tends to characterise the industry as a mass of uncoordinated segments without commonality. The singular form is therefore preferred because all sport segments should be regarded as a homogeneous entity.

\section{KEY CONCEPTS OF THE STUDY}

It is essential to define and explain the two key concepts used in this study before the research design and methodology are discussed.

\section{- Relationship marketing}

Many relationship marketing definitions are provided in services marketing, industrial marketing, bank marketing, advertising and business strategy. The understanding of relationship marketing requires a clear understanding of the difference between discrete transactions and relational exchanges. Morgan and Hunt (1994) propose that ".... relationship marketing refers to all marketing activities directed toward establishing, developing and maintaining successful relational exchanges." 


\section{- Relationship quality}

Relationship quality is described by Bejou, Wray and Ingram (1996) as an important component of relationship marketing. Morgan and Hunt (1994) identify five major antecedents of relationship quality. These are: (i) relationship termination costs, (ii) relationship benefits, (iii) shared values, (iv) opportunistic behaviour and (v) communication. Parasuraman, Zeithaml and Berry (1994) describe relationship quality as the difference between perceived relational benefits and perceived relationship sacrifice, and perceived episode benefits and perceived episode sacrifice, within the parameters of 'tolerance zones.'

\section{OBJECTIVES OF THE STUDY}

The primary objective was to determine the influence of the qualitative outcomes of relationship commitment and trust on the relationship quality between a service provider and a client.

The secondary objectives were:

(i) To compile a client profile to enable the service provider to direct its marketing strategy and to ensure the effectiveness of a future relationship marketing strategy.

(ii) To identify the gaps in the current relationship marketing strategy based on the client's perception of the service provider in order to enhance the effectiveness of a future relationship marketing strategy.

\section{RESEARCH DESIGN AND METHODOLOGY}

The total project was divided into two distinct phases - a pavilion survey (phase 1) and a mail survey (phase 2). The pavilion survey was used as a pretesting phase for the mail survey questionnaire.

\subsection{Questionnaire design}

The questionnaire included specific relationship marketing questions representing the quality of the relationship between the client and the service provider, value for 
money, propensity to leave and recommendation of the service provider to potential clients.

The main body of the questionnaire included 48 individual statements divided into eight categories. The statements were measured in terms of both importance and perception of performance. Both importance and perception of performance measures were done on a five point scale.

The questionnaire layout was carefully planned to accommodate the mail collection methodology used and was pretested during a pilot study before it was sent to the respondents in the sample.

\subsection{Data collection}

A probability sampling design (simple random sample) was used to draw a sample of 2000 units from the customer database (a sample frame of 3500) of the service provider. The sample units were randomly selected and thereafter the selfadministered questionnaires were distributed by mail.

\subsection{Data processing}

Factor analysis, cross tabulation and item reliability were executed and an analysis of variance was done by means of ANOVA by using CSS Statistica computer software.

\section{RESEARCH HYPOTHESES}

The following hypotheses were formulated and tested:

$\mathbf{H}_{1}$ The relationship quality of spectators that had a long relationship with the service provider is significantly higher than the relationship quality of spectators that have recently engaged in a relationship with the service provider.

$\mathbf{H}_{2}$ The relationship quality of spectators who regard their season tickets as good value for money is significantly higher than the relationship quality of spectators regarding their season tickets as less value for money. 
$\mathbf{H}_{3}$ The relationship quality of spectators who are willing to continue their current relationship is significantly higher than the relationship quality of spectators who are not willing to continue their current relationship with the service provider.

$\mathbf{H}_{4}$ The relationship quality of spectators who are willing to recommend the service provider to potential spectators is significantly higher than the relationship quality of spectators who are not willing to recommend the service provider to potential supporters.

$\mathbf{H}_{5}$ The relationship quality of spectators with a high perception of marketing effectiveness is significantly higher than the relationship quality of spectators with a low perception of marketing effectiveness.

$\mathbf{H}_{6}$ The relationship quality of spectators with a strong perception of image is significantly higher than the relationship quality of spectators with a low perception of image.

$\mathbf{H}_{7} \quad$ The relationship quality of spectators with a positive perception of media relationships is significantly higher than the relationship quality of spectators with a negative perception of media relationships.

\section{FINDINGS}

\subsection{Response rate}

The effective response rate of the mail survey sent to spectators (season ticket holders) was $25.50 \%$.

\subsection{Descriptive statistics on relationship quality}

The descriptive statistics indicate the sample size, mean, standard deviation, two-top box score in Table 1, the mean values in Table 2 . The two-top box score is an indication of the percentage of respondents who have chosen scale values 9 and 10 . Frequency distribution results in Table 3 is based on a 5 point scale and indicate the percentages of the responses on each scale item. 
Table 1: Deseriptive statistics

\begin{tabular}{|l|c|c|c|c|}
\hline & $* \mathbf{N}$ & $\begin{array}{c}\text { Mean } \\
(* * \mathbf{R a n g e})\end{array}$ & $\begin{array}{c}\text { Standard } \\
\text { deviation }\end{array}$ & $\begin{array}{c}\text { Two-top } \\
\text { box score }\end{array}$ \\
\hline Relationship quality & 484 & 6.22 & 2.28 & $11.60 \%$ \\
\hline Propensity to leave (PTL) & 484 & 6.72 & 2.27 & $19.90 \%$ \\
\hline Value for money (VFM) & 484 & 6.70 & 2.12 & $18.70 \%$ \\
\hline $\begin{array}{l}\text { Willingness to recommend } \\
\text { (WTR) }\end{array}$ & 484 & 6.67 & 2.24 & $18.20 \%$ \\
\hline
\end{tabular}

* $\quad \mathrm{N}=$ sample size

* The range of scale from $0-10$ where $0=$ very poor and $10=$ excellent

\subsection{Marketing effectiveness measurement}

Marketing effectiveness was measured on a 5-point Likert scale for both importance and perception of performance.

Figure 1: XY Plot of Marketing Effectiveness

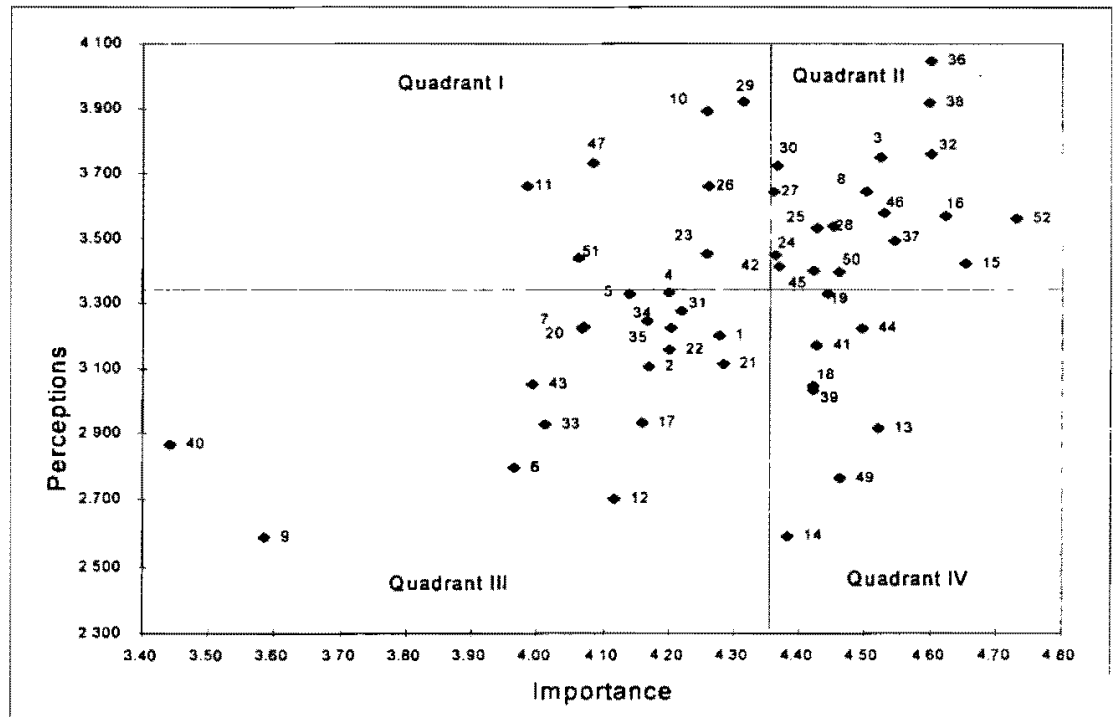


In order to subtract the most objective criteria for a quadrant separation, the mean value of each statement was used as the central measurement for both importance and perception of performance. With this approach it was possible to distinguish between the four distinct quadrants:

Quadrant I

Quadrant II

Quadrant III

Quadrant IV
Low importance, High Perception

High importance, High perception

Low importance, Low perception

High importance, Low perception

The mean scores for each statement on both importance and perception of performance are illustrated on the vertical and horizontal axis. Specific marketing problem areas are identified by the XY plot as the horizontal axis represents the column where the spectators provided an indication of the importance of each statement on a 5 point scale. The vertical axis represents the evaluation of the spectators' experience on each of the statements regarding the service provider. The individual statements were numerically identified according to their numerical sequence in the questionnaire. Both axis $\mathrm{X}$ and $\mathrm{Y}$ were restricted to a variance width of the scale rating. Based on the variance width for each axis, a decision was taken to restrict the scale values for importance to a maximum of 4.80 and a minimum of 3.40 , whilst the perception on performance scale was restricted to a maximum of 4.10 and a minimum of 2.3. The most important problem areas are identified in quadrant IV and represents the following statements:

\section{Quadrant IV}

\begin{tabular}{|c|l|c|c|}
\hline 14 & Image of the Sport Union's management & 4.383 & 2.590 \\
\hline 49 & $\begin{array}{l}\text { The amount of spectators visiting matches at the } \\
\text { stadium }\end{array}$ & 4.462 & 2.762 \\
\hline 13 & $\begin{array}{l}\text { Marketing to win and to keep the loyalty of the } \\
\text { spectators }\end{array}$ & 4.521 & 2.915 \\
\hline 39 & Parking in and around the stadium & 4.422 & 3.033 \\
\hline 18 & $\begin{array}{l}\text { Communication to spectators (keep spectators } \\
\text { informed) }\end{array}$ & 4.421 & 3.046 \\
\hline 41 & The sound system and public address system & 4.426 & 3.168 \\
\hline 44 & $\begin{array}{l}\text { Placement of regular match schedules and information } \\
\text { on other matches in newspapers }\end{array}$ & 4.495 & 3.222 \\
\hline
\end{tabular}

The range of scale from $1-5$ 
Quadrant II is a more positive quadrant and represents statements with a high importance and a high perception:

\section{Quadrant II}

\begin{tabular}{|c|l|c|c|}
\hline 36 & Neatness of the stadium & 4.602 & 4.048 \\
\hline 38 & Safety and security of the stadium & 4.598 & 3.918 \\
\hline 3 & The strong marketing identity & 4.525 & 3.746 \\
\hline 32 & Spirit of the stadium spectators & 4.601 & 3.754 \\
\hline 8 & Marketing of the sport to children & 4.503 & 3.641 \\
\hline 46 & Behaviour of the spectators on the pavilion & 4.530 & 3.575 \\
\hline 16 & Image of the players & 4.622 & 3.566 \\
\hline 52 & International exposure & 4.731 & 3.557 \\
\hline 37 & The toilet facilities at the stadium & 4.547 & 3.490 \\
\hline
\end{tabular}

The range of scale from $1-5$

\section{Table 2: Mean values}

\begin{tabular}{|l|c|c|}
\hline \multirow{2}{*}{} & \multicolumn{2}{|c|}{ Mean values (5 point scale) } \\
\cline { 2 - 3 } & Importance & $\begin{array}{c}\text { Perception of } \\
\text { performance }\end{array}$ \\
\hline Marketing & 4.21 & 3.19 \\
\hline Image & 4.63 & 3.09 \\
\hline Communication & 4.40 & 2.97 \\
\hline Tickets & 4.36 & 3.35 \\
\hline Involvement & 4.40 & 3.74 \\
\hline Stadium & 4.26 & 3.21 \\
\hline Media relationships & 4.35 & 3.15 \\
\hline Spectators & 3.60 & 3.21 \\
\hline
\end{tabular}

The mean values on importance are significantly higher than the mean values on perception of performance for all the categories. This result is an indication of the importance of all the categories to the clients and the weak performance of the service provider on these categories. 
Table 3: Frequency distribution table

\begin{tabular}{|c|c|c|c|c|}
\hline & $\begin{array}{c}\text { Relationship } \\
\text { quality }\end{array}$ & $\begin{array}{c}\text { Propensity to } \\
\text { leave }\end{array}$ & $\begin{array}{c}\text { Value for } \\
\text { money }\end{array}$ & $\begin{array}{c}\text { Willingness to } \\
\text { recommend }\end{array}$ \\
\hline $\mathbf{0}$ & $1.90 \%$ & $2.1 \%$ & $0.20 \%$ & $1.90 \%$ \\
\hline $\mathbf{1}$ & $1.90 \%$ & $0.80 \%$ & $0.60 \%$ & $1.20 \%$ \\
\hline $\mathbf{2}$ & $3.10 \%$ & $2.70 \%$ & $3.30 \%$ & $2.70 \%$ \\
\hline $\mathbf{3}$ & $6.80 \%$ & $4.10 \%$ & $5.00 \%$ & $3.50 \%$ \\
\hline $\mathbf{4}$ & $6.60 \%$ & $4.30 \%$ & $6.20 \%$ & $4.10 \%$ \\
\hline $\mathbf{5}$ & $17.80 \%$ & $13.00 \%$ & $11.20 \%$ & $14.50 \%$ \\
\hline $\mathbf{6}$ & $14.70 \%$ & $11.60 \%$ & $14.60 \%$ & $12.40 \%$ \\
\hline $\mathbf{7}$ & $17.40 \%$ & $19.30 \%$ & $20.70 \%$ & $19.30 \%$ \\
\hline $\mathbf{8}$ & $18.20 \%$ & $22.20 \%$ & $19.50 \%$ & $22.20 \%$ \\
\hline $\mathbf{9}$ & $3.50 \%$ & $9.30 \%$ & $7.70 \%$ & $8.30 \%$ \\
\hline $\mathbf{1 0}$ & $8.10 \%$ & $10.60 \%$ & $11.00 \%$ & $9.90 \%$ \\
\hline Total & $\mathbf{1 0 0} \%$ & $\mathbf{1 0 0} \%$ & $\mathbf{1 0 0} \%$ & $\mathbf{1 0 0 \%}$ \\
\hline
\end{tabular}

* The frequencies are the percentage of responses on each scale item.

* Willingness to continue the current relationship was measured as the inverse of propensity to leave.

\subsection{Validity and reliability}

Factor analysis was used to determine the validity of the data in the data set. Eight factors were extracted by principle component analysis and a Varimax rotation accounting for $62 \%$ of the variance in the importance section and $55 \%$ of the variance in the perception section. By employing the Varimax rotation method a rotated factor pattern was compiled and only items with factor loadings greater than 0.4 during this rotation have been included in the relevant factors. The factor loadings are an indication of the contribution of each item to the variance in each factor. Items $14,26,47$ and 48 were eliminated due to them not contributing to the significance norm of 0.4 .

These factors explain $62 \%$ (internal consistency) of the variation in the importance section of the data set and eight factors selected are shown in Table 4. The factors explain $55 \%$ (internal consistency) of the variation in the perception section of the data set and the eight factors selected are shown in Table 5. 
SAJEMS NS Vol 2 (1999) No 1

Table 4: Factor analysis based on importance

\begin{tabular}{|c|c|c|c|c|c|c|c|c|}
\hline Item & $\overline{\text { Fac- }}$ & Fac- & Fac- & Fac- & Factor & Fac- & Factor & Factor \\
\hline & tor 1 & tor 2 & tor 3 & tor 4 & 5 & tor 6 & 7 & 8 \\
\hline $\begin{array}{l}\text { Aggresive marketing of } \\
\text { rugby }\end{array}$ & & & 0.704 & & & & & \\
\hline $\begin{array}{l}\text { Advertising in newspaper, } \\
\text { magazines, radio \& TV }\end{array}$ & & & 0.698 & & & & & \\
\hline $\begin{array}{l}\text { The strong marketing } \\
\text { identity }\end{array}$ & & & 0.646 & & & & & \\
\hline $\begin{array}{l}\text { Using rugby players in } \\
\text { marketing }\end{array}$ & & & & & & 0.741 & & \\
\hline $\begin{array}{l}\text { The appearance of rugby } \\
\text { players at promotional } \\
\text { events }\end{array}$ & & & & & & 0.759 & & \\
\hline $\begin{array}{l}\text { Marketing/introducing of } \\
\text { new/young players to } \\
\text { spectators }\end{array}$ & & & & & & 0.552 & & \\
\hline Marketing of season tickets & & & 0.549 & & & & & \\
\hline $\begin{array}{l}\text { Marketing of rugby to } \\
\text { children }\end{array}$ & & & 0.440 & & & & & \\
\hline $\begin{array}{l}\text { Marketing of rugby to } \\
\text { women }\end{array}$ & & & 0.401 & & & & & \\
\hline $\begin{array}{l}\text { Using sponsorships in } \\
\text { marketing }\end{array}$ & & & 0.462 & & & & & \\
\hline $\begin{array}{l}\text { The use of rugby souveniers } \\
\text { (caps, jerseys, emblems, } \\
\text { cushions) }\end{array}$ & & & & & & & & 0.497 \\
\hline $\begin{array}{l}\text { Convincing non-rugby } \\
\text { spectators and } T V \\
\text { spectators to visit the } \\
\text { stadium }\end{array}$ & & & & & & & & 0684 \\
\hline $\begin{array}{l}\text { Marketing to win and to } \\
\text { keep the loyalty of the } \\
\text { spectators }\end{array}$ & & & & & & & & 0.642 \\
\hline The total image of the team & & & & & & & 0.783 & \\
\hline Image of the players & & & & & & & 0.772 & \\
\hline $\begin{array}{l}\text { The accessibility of the } \\
\text { Union to the public }\end{array}$ & & & & & 0.503 & & & \\
\hline
\end{tabular}


Table 4 continued

\begin{tabular}{|c|c|c|c|c|c|c|c|c|}
\hline Item & Fac- & Fac- & Fac- & Fac- & Factor & Fac- & Factor & actor \\
\hline & tor 1 & tor 2 & tor 3 & tor 4 & 5 & tor 6 & 7 & \\
\hline $\begin{array}{l}\text { Communication to } \\
\text { spectators (keep spectators } \\
\text { informed) }\end{array}$ & & & & & 0.501 & & & \\
\hline $\begin{array}{l}\text { Communication with the } \\
\text { media (newspapers, radio, } \\
\text { TV) }\end{array}$ & & & & & 0.481 & & & \\
\hline $\begin{array}{l}\text { The variety of ticket } \\
\text { packages marketed }\end{array}$ & & 0.437 & & & & & & \\
\hline The price of a season ticket & & 0.603 & & & & & & \\
\hline $\begin{array}{l}\text { The price of a ticket at the } \\
\text { gate }\end{array}$ & & 0.741 & & & & & & \\
\hline $\begin{array}{l}\text { The availibility of season } \\
\text { tickets }\end{array}$ & & 0.765 & & & & & & \\
\hline $\begin{array}{l}\text { The availability of tickets in } \\
\text { general }\end{array}$ & & 0.756 & & & & & & \\
\hline $\begin{array}{l}\text { Convenience to obtain a } \\
\text { ticket }\end{array}$ & & 0.718 & & & & & & \\
\hline $\begin{array}{l}\text { The involvement in club } \\
\text { rugby }\end{array}$ & & & & 0.706 & & & & \\
\hline $\begin{array}{l}\text { The involvement with school } \\
\text { rugby }\end{array}$ & & & & 0.747 & & & & \\
\hline $\begin{array}{l}\text { The involvement with junior } \\
\text { rugby }\end{array}$ & & & & 0.743 & & & & \\
\hline $\begin{array}{l}\text { The involvement with rugby } \\
\text { clinics }\end{array}$ & & & & 0.765 & & & & \\
\hline $\begin{array}{l}\text { The curtain-raisers during } \\
\text { important matches }\end{array}$ & 0.430 & & & & & & & \\
\hline Spirit of the spectator & 0.569 & & & & & & & \\
\hline $\begin{array}{l}\text { The entertainment of the } \\
\text { spectators to build } \\
\text { atmosphere (music } \\
\text { professional announcer) }\end{array}$ & 0.324 & & & & & & & \\
\hline $\begin{array}{l}\text { Catering facilities at the } \\
\text { stadium }\end{array}$ & 0.717 & & & & & & & \\
\hline Quality of the food & 0.747 & & & & & & & \\
\hline Neatness of the stadium & 0.753 & & & & & & & \\
\hline
\end{tabular}


Table 4 continued

\begin{tabular}{|l|l|l|l|l|l|l|l|l|}
\hline \multicolumn{1}{|c|}{ Item } & $\begin{array}{l}\text { Fac- } \\
\text { tor } 1\end{array}$ & $\begin{array}{l}\text { Fac- } \\
\text { tor } 2\end{array}$ & $\begin{array}{l}\text { Fac- } \\
\text { tor } 3\end{array}$ & $\begin{array}{c}\text { Fac- } \\
\text { tor } 4\end{array}$ & $\begin{array}{c}\text { Factor } \\
\text { Fac- }\end{array}$ & $\begin{array}{c}\text { Factor } \\
\text { tor } 6\end{array}$ & $\begin{array}{c}\text { Factor } \\
8\end{array}$ \\
\hline $\begin{array}{l}\text { The toilet facilities at the } \\
\text { stadium }\end{array}$ & 0.766 & & & & & & & \\
\hline $\begin{array}{l}\text { Safety \& security of the } \\
\text { stadium }\end{array}$ & 0.691 & & & & & & & \\
\hline $\begin{array}{l}\text { Parking in and around the } \\
\text { stadium }\end{array}$ & 0.598 & & & & & & & \\
\hline $\begin{array}{l}\text { The accessibility of } \\
\text { spectators to players after a } \\
\text { match }\end{array}$ & & & & & & 0.510 & & \\
\hline $\begin{array}{l}\text { The sound system and public } \\
\text { adress system }\end{array}$ & 0.508 & & & & & & & \\
\hline Publicity in newspapers & & & & & 0.530 & & & \\
\hline Talk shows on radio & & & & & 0.667 & & & \\
\hline $\begin{array}{l}\text { Placement of regular match } \\
\text { schedules and information } \\
\text { on other matches in } \\
\text { newspapers }\end{array}$ & & & & & 0.495 & & & \\
\hline $\begin{array}{l}\text { Maintaining effective media } \\
\text { relationships }\end{array}$ & & & & & 0.565 & & & \\
\hline $\begin{array}{l}\text { Behaviour of the spectators } \\
\text { on the pavilion }\end{array}$ & 0.495 & & & & & & & \\
\hline
\end{tabular}

Table 5: Factor analysis based on perception of performance

\begin{tabular}{|l|c|c|c|c|c|c|c|c|}
\hline \multicolumn{1}{|c|}{ Item } & $\begin{array}{c}\text { Fac- } \\
\text { tor } 1\end{array}$ & $\begin{array}{c}\text { Fac- } \\
\text { tor 2 }\end{array}$ & $\begin{array}{c}\text { Factor } \\
3\end{array}$ & $\begin{array}{c}\text { Fac- } \\
\text { tor } 4\end{array}$ & $\begin{array}{c}\text { Fac- } \\
\text { tor } 5\end{array}$ & $\begin{array}{c}\text { Fac- } \\
\text { tor } 6\end{array}$ & $\begin{array}{c}\text { Factor } \\
7\end{array}$ & $\begin{array}{c}\text { Fac- } \\
\text { tor } 8\end{array}$ \\
\hline $\begin{array}{l}\text { Aggresive marketing of } \\
\text { rugby }\end{array}$ & 0.553 & & & & & & & \\
\hline $\begin{array}{l}\text { Advertising in newspaper, } \\
\text { magazines, radio \& TV }\end{array}$ & 0.522 & & & & & & & \\
\hline $\begin{array}{l}\text { The strong marketing } \\
\text { identity }\end{array}$ & 0.471 & & & & & & & \\
\hline $\begin{array}{l}\text { Using rugby players in } \\
\text { marketing }\end{array}$ & 0.679 & & & & & & & \\
\hline $\begin{array}{l}\text { The appearence of rugby } \\
\text { players at promotional } \\
\text { events }\end{array}$ & 0.670 & & & & & & & \\
\hline
\end{tabular}


Table 5 continued

\begin{tabular}{|c|c|c|c|c|c|c|c|c|}
\hline Item & $\begin{array}{l}\text { Fac- } \\
\text { tor } 1\end{array}$ & $\begin{array}{l}\text { Fac- } \\
\text { tor } 2\end{array}$ & $\begin{array}{l}\text { Fac- } \\
\text { tor } 3\end{array}$ & $\begin{array}{l}\text { Fac- } \\
\text { tor } 4\end{array}$ & $\begin{array}{c}\text { Factor } \\
5\end{array}$ & $\begin{array}{l}\text { Fac- } \\
\text { tor } 6\end{array}$ & $\begin{array}{c}\text { Factor } \\
7\end{array}$ & $\begin{array}{c}\text { Factor } \\
8\end{array}$ \\
\hline $\begin{array}{l}\text { Marketing/introducing of } \\
\text { new/young players to } \\
\text { spectators }\end{array}$ & 0.685 & & & & & & & \\
\hline $\begin{array}{l}\text { Marketing of season } \\
\text { tickets }\end{array}$ & 0.631 & & & & & & & \\
\hline $\begin{array}{l}\text { Marketing of rugby to } \\
\text { children }\end{array}$ & 0.524 & & & & & & & \\
\hline $\begin{array}{l}\text { Marketing of rugby to } \\
\text { women }\end{array}$ & 0.606 & & & & & & & \\
\hline $\begin{array}{l}\text { Using sponsorships in } \\
\text { marketing }\end{array}$ & 0.555 & & & & & & & \\
\hline $\begin{array}{l}\text { The use of rugby } \\
\text { souveniers (caps, jerseys, } \\
\text { emblems, cushions) }\end{array}$ & 0.531 & & & & & & & \\
\hline $\begin{array}{l}\text { Convincing non-rugby } \\
\text { spectators and TV } \\
\text { spectators to visit the } \\
\text { stadium }\end{array}$ & 0.656 & & & & & & & \\
\hline $\begin{array}{l}\text { Marketing to win and to } \\
\text { keep the loyalty of the } \\
\text { spectators }\end{array}$ & 0.598 & & & & & & & \\
\hline $\begin{array}{l}\text { The total image of the } \\
\text { team }\end{array}$ & & & & & & 0.761 & & \\
\hline Image of the players & & & & & & 0.786 & & \\
\hline $\begin{array}{l}\text { The accessibility of the } \\
\text { Union to the public }\end{array}$ & & & & & & & & 0.333 \\
\hline $\begin{array}{l}\text { Communication to } \\
\text { spectators (keep } \\
\text { spectators informed) }\end{array}$ & & 0.426 & & & & & & \\
\hline $\begin{array}{l}\text { Communication with the } \\
\text { media (newspapers, radio, } \\
\text { TV) }\end{array}$ & & 0.555 & & & & & & \\
\hline $\begin{array}{l}\text { The variety of ticket } \\
\text { packages marketed }\end{array}$ & & & 0.521 & & & & & \\
\hline $\begin{array}{l}\text { The price of a season } \\
\text { ticket }\end{array}$ & & & 0.566 & & & & & \\
\hline $\begin{array}{l}\text { The price of a ticket at the } \\
\text { gate }\end{array}$ & & & 0.564 & & & & & \\
\hline $\begin{array}{l}\text { The availibility of season } \\
\text { tickets }\end{array}$ & & & 0.735 & & & & & \\
\hline
\end{tabular}


Table 5 continued

\begin{tabular}{|l|l|l|l|l|l|l|l|l|}
\hline \multicolumn{1}{|c|}{ Item } & $\begin{array}{l}\text { Fac- } \\
\text { tor 1 }\end{array}$ & $\begin{array}{l}\text { Fac- } \\
\text { tor 2 }\end{array}$ & $\begin{array}{l}\text { Fac- } \\
\text { tor 3 }\end{array}$ & $\begin{array}{c}\text { Fac- } \\
\text { tor 4 }\end{array}$ & $\begin{array}{c}\text { Factor } \\
5\end{array}$ & $\begin{array}{l}\text { Fac- } \\
\text { tor 6 }\end{array}$ & $\begin{array}{c}\text { Factor } \\
7\end{array}$ & $\begin{array}{c}\text { Factor } \\
8\end{array}$ \\
\hline $\begin{array}{l}\text { The availability of tickets } \\
\text { in general }\end{array}$ & & & 0.754 & & & & & \\
\hline $\begin{array}{l}\text { Convenience to obtain a } \\
\text { ticket }\end{array}$ & & & 0.666 & & & & & \\
\hline $\begin{array}{l}\text { The involvement in club } \\
\text { rugby }\end{array}$ & & & & 0.713 & & & & \\
\hline $\begin{array}{l}\text { The involvement with } \\
\text { school rugby }\end{array}$ & & & & 0.735 & & & & \\
\hline $\begin{array}{l}\text { The involvement with } \\
\text { junior rugby }\end{array}$ & & & & 0.745 & & & & \\
\hline $\begin{array}{l}\text { The involvement with } \\
\text { rugby clinics }\end{array}$ & & & & 0.731 & & & & \\
\hline $\begin{array}{l}\text { The curtain-raisers during } \\
\text { important matches }\end{array}$ & & & & & & & & 0.411 \\
\hline Spirit of the spectator & & & & & & & & 0.436 \\
\hline $\begin{array}{l}\text { The entertainment of the } \\
\text { spectators to build } \\
\text { atmosphere (music, } \\
\text { professional announcer) }\end{array}$ & & & & & & & & 0.535 \\
\hline $\begin{array}{l}\text { Catering facilities at the } \\
\text { stadium }\end{array}$ & & & & & & & 0.830 & \\
\hline Quality of the food & & & & & & & 0.837 & \\
\hline Neatness of the stadium & & & & & 0.740 & & & \\
\hline $\begin{array}{l}\text { The toilet facilities at the } \\
\text { stadium }\end{array}$ & & & & & 0.724 & & & \\
\hline $\begin{array}{l}\text { Safety \& security of the } \\
\text { stadium }\end{array}$ & & & & & 0.625 & & & \\
\hline $\begin{array}{l}\text { Parking in and around the } \\
\text { stadium }\end{array}$ & & & & & & & 0.412 & \\
\hline $\begin{array}{l}\text { The accessibility of } \\
\text { spectators to players after } \\
\text { a match }\end{array}$ & & & & & & & 0.439 & \\
\hline $\begin{array}{l}\text { The sound system and } \\
\text { public adress system }\end{array}$ & & 0.438 & & & & & & \\
\hline Publicity in newspapers & & 0.702 & & & & & & \\
\hline Talk shows on radio & & 0.637 & & & & & & \\
\hline $\begin{array}{l}\text { Placement of regular } \\
\text { match schedules and } \\
\text { information on other } \\
\text { matches in newspapers }\end{array}$ & & 0.652 & & & & & & \\
\hline
\end{tabular}


Table 5 continued

\begin{tabular}{|l|c|c|c|c|c|c|c|c|}
\hline \multicolumn{1}{|c|}{ Item } & $\begin{array}{c}\text { Fac- } \\
\text { tor 1 }\end{array}$ & $\begin{array}{c}\text { Fac- } \\
\text { tor 2 }\end{array}$ & $\begin{array}{c}\text { Fac- } \\
\text { tor 3 }\end{array}$ & $\begin{array}{c}\text { Fac- } \\
\text { tor 4 }\end{array}$ & $\begin{array}{c}\text { Factor } \\
5\end{array}$ & $\begin{array}{c}\text { Fac- } \\
\text { tor 6 }\end{array}$ & $\begin{array}{c}\text { Factor } \\
7\end{array}$ & $\begin{array}{c}\text { Factor } \\
8\end{array}$ \\
\hline $\begin{array}{l}\text { Maintaining effective } \\
\text { media relationships }\end{array}$ & & 0.676 & & & & & & 1 \\
\hline $\begin{array}{l}\text { Behaviour of the pavilion } \\
\text { spectators }\end{array}$ & & & & & 0.448 & & & \\
\hline
\end{tabular}

All the items identified in factors 1-5 and 7-8 were very consistent except for the items in factor 6 and there were no overlapping of items in factors 1-8.

The following items were the major contributors to each factor in the perception of performance:

Factor 1 Marketing and introducing of new / young players to spectators (item 6).

Factor 2 Publicity in newspapers (item 42).

Factor 3 The availability of tickets in general (item 24).

Factor 4 Involvement with junior sport (item 29).

Factor 5 Neatness of the stadium (item 36).

Factor 6 Image of the players (item 16).

Factor 7 Quality of food (item 35).

Factor 8 The entertainment of the spectators to build atmosphere (item 33).

Reliability was computed by means of the Cronbach alpha coefficient. Reliability results of these factors were computed by means of Cronbach alpha based on the total data, importance and perception of performance. The reliability result for the total evaluation of the data set is $95,12 \%$ and reliability for importance and perception of performance are shown in Table 6.

Table 6: Reliability results based on importance and perception

\begin{tabular}{|c|c|c|}
\hline Items & $\begin{array}{l}\text { Reliability for } \\
\text { importance }\end{array}$ & $\begin{array}{l}\text { Reliability for } \\
\text { perception on } \\
\text { performance }\end{array}$ \\
\hline (items I - 13) & $85,85 \%$ & $88,96 \%$ \\
\hline (items $14-16)$ & $83,88 \%$ & $76,22 \%$ \\
\hline Communication (items 17-19) & $79,81 \%$ & $72,80 \%$ \\
\hline (items $20-25)$ & $86,41 \%$ & $80,43 \%$ \\
\hline
\end{tabular}




\section{Table 6 continued}

\begin{tabular}{|c|c|c|}
\hline Items & $\begin{array}{l}\text { Reliability for } \\
\text { importance }\end{array}$ & $\begin{array}{l}\text { Reliability for } \\
\text { perception on } \\
\text { performance }\end{array}$ \\
\hline (items $26-30$ ) & $87,56 \%$ & $81,00 \%$ \\
\hline (items $31-41$ ) & $87,21 \%$ & $76.62 \%$ \\
\hline Media relationships (items $42-45$ ) & $82,43 \%$ & $80,60 \%$ \\
\hline (items $46-48$ ) & $29,03 \%$ & $27,55 \%$ \\
\hline
\end{tabular}

The reliability results for both importance and perception of performance are relatively high, considering that a standardised measurement instrument was not used. A Cronbach alpha coefficient of more than $70 \%$ was used as the norm and all items were found to be reliable except for items $46-48$. The reason for the low reliability on these items can be possibly ascribed to the controversial aspect of playing sport on a Sunday.

\subsection{Hypotheses testing}

Two-tailed hypotheses were used in order to perform tests for significant differences based on the p-value and to provide direction (higher and lower). ANOVA was used to determine the difference between categories 1 and 2 as described in Table 7.

Subjective criteria were determined for the qualitative labels "high" and "low". On the $0-10$ point scale, a qualitative label of "high" was assigned for scale values between 7-10 and the "low" label was assigned to scale values less than 7 .

\subsection{ANOVA}

Analysis of variance (ANOVA) was used to examine group differences on a single dependent variable. The dependent variable of relationship quality measured the effect of the various independent variables on the spectator's perception (test units) of the service provider's perception. The ANOVA results for the different hypotheses are summarised in Table 7. 


\section{Table 7: ANOVA results}

\begin{tabular}{|c|c|c|c|}
\hline \multicolumn{2}{|c|}{ Variable } & & \\
\hline Independent & Dependent & Mean & p-value \\
\hline $\begin{array}{l}\text { LOT [Category 1: } 1-2 \text { years] } \\
\text { LOT [Category 2: }>3 \text { years] }\end{array}$ & $\begin{array}{c}\text { Relationship } \\
\text { quality }\end{array}$ & $\begin{array}{l}5.32 \\
7.21\end{array}$ & 0.0001 \\
\hline $\begin{array}{l}\text { VFM [Category 1: } 0-6] \\
\text { VFM [Category } 2: 7-10]\end{array}$ & $\begin{array}{l}\text { Relationship } \\
\text { quality }\end{array}$ & $\begin{array}{l}5,17 \\
6,95\end{array}$ & 0.0001 \\
\hline 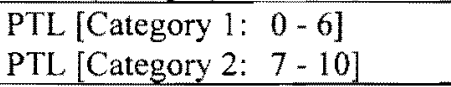 & $\begin{array}{l}\text { Relationship } \\
\text { quality }\end{array}$ & $\begin{array}{l}4,89 \\
7,03\end{array}$ & 0.0001 \\
\hline $\begin{array}{l}\text { WTR [Category 1:0-6] } \\
\text { WTR [Category 2:7- } 10]\end{array}$ & $\begin{array}{l}\text { Relationship } \\
\text { quality }\end{array}$ & $\begin{array}{l}4,92 \\
7,08\end{array}$ & 0.0001 \\
\hline $\begin{array}{ll}\text { MEFF [Category 1: } & 1-3] \\
\text { MEFF [Category 2: } & 4-5]\end{array}$ & $\begin{array}{l}\text { Relationship } \\
\text { quality }\end{array}$ & $\begin{array}{l}5,66 \\
6,56\end{array}$ & 0.0001 \\
\hline $\begin{array}{ll}\text { Image [Category 1: } & 1-3 \text { ] } \\
\text { Image [Category 2: } & 4-5 \text { ] }\end{array}$ & $\begin{array}{l}\text { Relationship } \\
\text { quality }\end{array}$ & $\begin{array}{l}5,49 \\
7,10\end{array}$ & 0.0001 \\
\hline $\begin{array}{ll}\text { COMM [Category 1: } & 1-3] \\
\text { CoMM [Category 2: } & 4-5]\end{array}$ & $\begin{array}{l}\text { Relationship } \\
\text { quality }\end{array}$ & $\begin{array}{l}5,77 \\
6,92\end{array}$ & 0.0001 \\
\hline
\end{tabular}
* LOT $=$ Length of time
* PTL $=$ Propensity to leave
* $\mathrm{MEFF}=$ Marketing effectiveness
* $V F M=$ Value for money
* WTR $=$ Willingness to recommend
* $\mathrm{COMM}=$ Communication

All hypotheses were accepted based on the differences in the mean values of the different categories and are statistically significant based on the p-value for each ANOVA result.

\section{CONCLUSION}

The findings of the empirical study can be regarded as valid and reliable based on the research results. The overall reliability for the evaluation of the data set is a reliability coefficient of 0.9512 and the scientific execution of the methodology increased the validity of the results.

Based on the validity and reliability results of this study, the following major conclusions are drawn: 
- Relationship quality is influenced by the duration a spectator is engaged in the relationship with a service provider. The longer the-relationship a spectator has with a service provider the higher the quality of the current relationship.

- The quality of the relationship is influenced by the spectator's perceived value for money based on his experience of the service provided to him by the service provider. The higher the perceived value for money the higher the quality of the current relationship.

- Propensity of a spectator not to leave or not to terminate the current relationship with a service provider influences the relationship quality between a service provider and a client. The higher the quality of the relationship the lower the propensity to leave and to terminate a current relationship with a service provider.

- Willingness of a spectator to recommend his current service provider to a potential client influences the quality of the current relationship between a service provider and a spectator. The higher the quality of the current relationship the higher the willingness of a spectator will be to recommend the service provider to a potential spectator or spectators.

- The quality of the current relationship between a service provider and a spectator is influenced by a spectator's perception on the marketing effectiveness of a service provider. The higher the spectator's perception of marketing effectiveness the higher the quality of the current relationship with a service provider.

\section{RECOMMENDATIONS FOR FUTURE RESEARCH}

Recommendations for future research are divided into recommendations based on the literature review and recommendations based on the empirical research.

\section{- Recommendations based on the literature review}

Firstly, more literature is needed on marketing and relationship marketing focusing on sport. 
Secondly, more literature is needed on relationship marketing in a business-toconsumer (BTC) environment.

\section{- Recommendations based on the empirical research}

Firstly, to develop a relationship quality model by applying the RELQUAL model (Ewing, 1996) specifically on rugby and on professional sport unions in general and to compare the findings across different sport unions and administrations.

Secondly, to develop a marketing mix specifically for rugby and professional sport unions in general.

Thirdly, to determine the effect of a winning team on the marketing effectiveness, on short and long term relationship quality with a sport union and to investigate the effect that a winning team has on the relationship quality of the stakeholders and spectators.

Fourthly, to develop a marketing orientation for management of sport unions, officials and players.

\section{REFERENCES}

1. BERRY, R. (1994), "Laying Foundation for Future Sales", Trusts \& Estates, 95(5):58.

2. BEJOU, D., WRAY, B. \& INGRAM, T.N. (1996), "Determinants of Relationship Quality: An Artificial Neural Network Analysis", Journal of Business Research, 36(2):137-143.

3. GRUEN, T.W. (1995), "The Outcome Set of Relationship Marketing in Consumer markets", International Business Review, 4(4):447-469.

4. MORGAN, R.M. and HUNT, S.B. (1994), "The Commitment-Trust Theory of Relationship Marketing", Journal of Marketing, 58:20-38.

5. MULLIN, B.J., HARDY, S. \& SUTTON, W. (1993), Sport Marketing. Human Kinetics.

6. PALEY N. MAR (1996), "Romancing Your Customers", Sales \& Marketing

7. PARASURAMAN A., ZEITHAML, V. \& BERRY, L.L. (1994), "Reassessment of Expectations as a Comparison Standard in Measuring Service Quality: Implications for Future Research", Journal of Marketing, 58:111124. 
8. PERRIEN, J. \& RICHARD, L. (1995) "The Meaning of Relationship Marketing", Industrial Marketing Management, 24(1):37-43.

9. PRUDEN, D. (1995) "Retention Marketing Gains Spotlight", Brandweek, $36(6): 15$. 